\title{
Diksi Cermin Realita Budaya dalam Lirik Lagu Populer Indonesia
}

\author{
M. Hermintoyo \\ Fakultas Ilmu Budaya, Universitas Diponegoro \\ hermintpujangga@Gmail.com
}

\begin{abstract}
Creative authors will be sensitive to their environment and their development according to their times. Through the diction that is used shows the ability of the author in writing song lyrics. Understanding the song lyrics is not only understanding the language code, but requires the literary code and cultural code. Lyrics in the language code seen in their basic form are meaningful series of words. The words used in showing its beauty are manifested as poetry or lyrics whose meanings are figurative. These figurative words can be seen in the intrinsic elements of majas-literary works and so on. These words are used by the author as a means of creativity through the existing reality in the form of cultural codes. Culture that lives in the community is used as a metaphorical symbol that reflects its experience and knowledge. For connoisseurs of the work can be accepted if there is the same knowledge about the cultural code.
\end{abstract}

Keywords: lyrics, diction, figurative, language code, literary code, cultural code

\section{Intisari}

Pengarang yang kreatif akan peka terhadap lingkungannya dan perkembangannya sesuai zamannya. Lewat diksi yang dipakai menunjukkan kemampuan pengarang dalam menulis lirik lagu.Memahami lirik lagu tidak hanya memahami kode bahasanya saja, tetapi memerlukan kode sastra dan kode budayanya. Lirik dalam kode bahasa terlihat dalam wujud dasarnya adalah rangkaian kata yang bermakna. Kata-kata tersebut dipakai dalam menunjukkan keindahannya diwujudkan sebagai puisi atau lirik yang makna katanya figuratif. Kata-kata figuratif itu terlihat dalam unsur intrinsik karya sastra berdiksi majas dst. Kata-kata tersebut dipakai pengarang sebagai sarana kreativitas melalui realita yang ada berupa kode budaya. Budaya yang hidup dimasyarakat dipakai sebagi simbol metaforis yang mencereminkan pengalaman dan pengetahuannya. Bagi penikmat karya hal itu dapat diterima jika ada pengetahuan yang sama tentang kode budaya tersebut.

\section{Kata kunci: lirik, diksi, figuratif, kode bahasa, kode sastra, kode budaya}

\section{Pendahuluan}

Memahami teks lirik lagu tak ubahnya memahami teks puisi. Keduanya membutuhkan pemahaman unsur fisik, seperti: diksi, rima, imaji, sarana retorika dan pemahaman makna yang ada dalam teks tersebut (Waluyo,1987:23; Aminudin, 2000:136).. Teks tersebut merupakan alat komunikasi pengarang/ penyanyi terhadap audiennya. Dengan demikian pemahaman makna harus ada kesamaan pengetahuan dalam berkomunikasi. Makna 
terbentuk secara arbitrer dan konvensional. Makna itu menjadi khazanah pengetahuan masyarakat sebagai sarana untuk berkomunikasi, bahkan Whorf dalam ( Sudaryono, 2000:13) mengatakan "bukan saja merupakan instrumen untuk berkomunikasi dalam kehidupan, namun sebenarnya juga mendifinisikan kehidupan itu sendiri."

Tanda bahasa selain menyatakan makna konvensional juga mengandung implikatur, yaitu sesuatu yang ditangkap oleh pendengar/pembaca yang berbeda dari makna konvensionalnya.Suyono(1990:14) mengatakan implikatur sebagai salah satu aspek kajian pragmatik perhatian utamanya adalah mempelajari maksud suatu ucapan sesuai dengan konteksnya.Dengan perkataan lain, implikatur dipakai untuk menerangkan makna implisit dibalik apa yang diucapkan/dituliskan sebagai sesuatu yang diimplikasikan, misalnya kalimat (1)" Dua angsa memadu rindu" ( Katon:Pasangan Jiwa). Pra anggapan kalimat itu (1) angsa putih, (2) angsa hitam, (3) angsa bercumbu, (4) angsa kawin, (5) dua sejoli (sedang pacaran, bercumbu, kawin). Kalimat tersebut dapat disimpulkan berdasarkan konteksnya atau hubungan dengan kalimat-kalimat lain dalam bait lagu tersebut, implikasinya menjelaskan angsa sebagai symbol sejoli yang sedang bercumbu/ bermesraan.

Pemahaman terhadap implikatur didasarkan atas praanggapan sebagai pengetahuan bersama (commond ground) di antara pembicara dan pendengar. Angsa adalah simbol yang disepakati dalam budaya universal. Dalam perkawinan sering digambarkan atau dipasang mainan sepasang angsa sebagai simbol percintaan.

Makna konvensional terkodifikasikan ke dalam kamus-kamus bahasa, sedangkan makna implikatur menjadi pengetahuan yang hidup dan dinamis dan tidak terdapat dalam kamus-kamus. Hal ini disebabkan implikatur bersifat lokal, dan relatif cepat berubah. Perubahan ini ditentukan oleh kebenaran pemahaman masyarakat terhadap proses yang dituturkan. Apabila seseorang menuturkan sesuatu dengan maksud sesuai dengan makna konvensionalnya, maka muncul implikatur yang berbeda makna konvensionalnya. Munculnya implikatur yang berbeda dengan makna konvensionalnya mengakibatkan tuturan bersifat taksa (karena menimbulkan interprestasi ganda ) karena itu potensial menimbulkan kesalahpahaman dalam berkomunikasi (Sudaryono 2000:13-14). Agar tuturan tidak taksa, peranan konteks sangat dibutuhkan. Pembiasan makna yang muncul harus dicari sesuai konteksnya melalui medan kata 
Menurut Trier (dalam Wedhawati 1993:12-13), sejumlah kata yang membentuk medan itu bagaikan bahan mozaik yang membagi dan membatasi medan konseptual, yang terdiri atas satuan-satuan konseptual. Susunan medan konseptual itu tampak pada susunan medan katanya. Medan kata identik dengan konsep, dan konsep identik dengan makna. Yang dimaksud dengan makna adalah makna medan kata. Makna kata hanya dapat diidentifikasi berdasarkan relasinya dengan makna kata yang lain dalam sebuah medan kata, sehingga pembiasan makna, seperti (6) "coba bertanya pada rumput bergoyang" (Ebid G Ade: Berita Kepada Kawan) dapat dipranggapkan dengan hubungan kata rumput itu berwarna hijau, hijau itu segar, segar itu hidup; bergoyang itu bergerak, begerak itu hidup jadi ada kehidupan, kehidupan itu diciptakan, yang menciptakan adalah Tuhan, jadi kesimpulanya bertanyalah pada yang memberi kehidupan, yaitu Tuhan. Lirik lagu berupa teks, menurut Luxemburg (1984:86) teks adalah ungkapan bahasa yang memuat isi, sintaksis, dan pragmatik yang merupakan suatu kesatuan. Teks tersebut bisa berupa lisan maupun tertulis. Kesatuan ada tiga aspek, yaitu (1) kesatuan pragmatik: bagaimana bahasa digunakan dalam suatu konteks; (2) kesatuan sintaktik: teks harus menunjukkan kebertautan; (3) kesatuan semantik: tema global yang melingkupi semua unsur / berfungsi sebagai ikhtisar teks/ simboliknya. Sesuai dengan kajian, penelitian ini lebih difokuskan pada pragmatik, yaitu pemakaian kebahasaan yang dihubungkan dengan konteks. Teeuw (1983:12) berpendapat bahwa wacana sastra merupakan penggunaan bahasa yang khas yang hanya dapat dipahami dengan pengertian konsepsi bahasa yang tepat. Untuk menangkap makna dalam karya sastra diperlukan pemahaman tiga macam kode, yaitu: kode bahasa, kode sastra, dan kode budaya.

Pemahaman suatu bahasa akan lengkap jika dipahami kode budaya yang melatarinya. Proses berbahasa sangat ditentukan oleh konteks budayanya sehingga pemahaman katakata atau ungkapan maknanya terikat kode budaya secara konvensional, dan harus bisa dipahami dari kedua pihak (penutur dan mitratutur). Dalam bahasa puisi/lirik pun diperlukan pemahaman semacam itu meskipun dalam pelaksanaannya pemahamannya menjadi bias. Memahami puisi itu diperlukan "cultural understanding" dari penyimak. Tidak ada karya sastra yang lahir atas kekosongan budaya, sebagaimana bahasa dalam karya sastra itu sendiri merupakan produk masyarakat yang mempunyai makna yang didasarkan pada konvensi masyarakat sehubungan dengan laku budayanya (Hermintoyo, 2017:89). 


\section{Metode}

Metode yang digunakan dalam pemerolehan data adalah metode pustaka dengan teknik simak catat. Langkah-langkah yang dilakukan adalah membaca berulang-ulang kemudian disimak dan dicatat diklasivikasikan sesuai kebutuhan penelitian. Data diambil dengan menggunakan teknik porposive sampling disesuaikan kebutuhan penelitian. Analisis data menggunakan kode bahasa, kode sastra, dan kode budaya untuk melihat simbol-simbol yang digunakan dengan bacaan hermeunetika. Pradopo (1987:122) menjelaskan "Pengetahuan tentang kode bahasa belumlah cukup untuk menyingkap makna puisi. Makna puisi bukan semata-mata arti bahasanya, melainkan arti bahasa dan suasana, perasaan, intenbsitas arti, arti tambahan, daya tarik dan tanda-tanda kebahasaan." Tanda tanda kebahasaan itu terlihat pada makna simbol yang hidup dalam kebudayaan tertentu.

\section{Hasil dan Pembahasan}

\section{Metafora tentang Nama}

Mitos sebagai kepercayaan diyakini masayarakat pendukungnya dapat memberi kekuatan, berkah, kebenaran dsb. Mitos itu hidup dalam kebudayaan masyarakat pendukungnya. Ada yang diyakini secara universal, dan yang lokal. Secara universal diakui dibelahan dunia, sedangkan yang lokal bersifat kedaerahan. Misal matahari sebagai simbol kekuatan, angin sebagai simbol kehidupan adalah mitos universal, sedangkan yang lokal misalnya janur (daun kelapa) simbol orang punya hajat, dan simbol keperawanan dalam hiasan hajat perkawinan di Jawa. Nama sebagai mitos yang dimiliki masyarakat tertentu merupakan simbol yang mengarahkan kekongkritan makna kekuatan, berkah dsb. Misalnya metafora dalam larik lagu berikut

(7) Akulah Arjuna yang mencari cinta

Wahai wanita, cintailah aku

Mungkin kutemui cinta sejati

Saat aku hembuskan nafas terakhirku

Mungkin cinta sejati memang tak ada dalam cerita kehidupan ini Akulah Arjuna $6 x$

(Dewa: Arjuna Mencari Cinta)

Arjuna di dalam larik itu mengambil nama tokoh pewayangan yang ganteng, satria, sakti, istrinya banyak. Mitos orang Jawa meyakini dengan memberi nama Arjuna setidaknya akan mewarisi fisik, psikis, dan kesaktian Arjuna yang dikenal sebagai 
"lelananging jagad, sakti mondro guno". Dalam karier bercinta Arjuna tidak pernah gagal dan harus mendapatkan keperawanan seperti dalam perjalanan cerita cintanya di pewayangan, tetapi Arjuna dalam larik itu sedang dalam proses. Setidak-tidaknya dengan nama Arjuna seseorang itu bersugesti akan berhasil seperti Arjuna yang tidak pernah gagal dalam bercinta.

Demikian juga dengan tokoh Rama-Shinta dalam pewayangan Ramayana sebagai simbol kesetiaan dan kesucian cinta menjadi panutan bagi orang Jawa bahkan di asal cerita itu dibuat, yaitu India. Gathotkaca tokoh yang berotot kawat dan berbalung (kerangka) besi , dan dapat terbang adalah simbol tokoh yang bertubuh kuat, pemberani dan siap bertempur di medan laga dalam pewayangan Mahabarata meskipun dalam peperangan Gatot kaca dijadikan korban kelicikan yang dilakukan para sais baik dari Kurawa maupun Pandawa sehingga nyawa Harjuna terselamatkan. Harjuna bukanlah tokoh yang jujur dalam peperangan karena ada permainan dalam pertarungannya dengan Karna. Orang Jawa terutama, sangat mengagumi keprajuritan Harjuna, keperkasaan Harjuna yang beristri banyak, juga berpoliandri dengan saudaranya dinikahi Drupadi, belum lagi perilaku seksnya yang menyimpang menikahi Srikandi (dalam cerita aslinya Srikandi adalah lelaki/ wadam). Kesalahan siapa sehingga orang Jawa mengagumi Pandawa (Harjuna) berlebihan sehingga dijadikan panutan, termasuk menggunakan nama Harjuna. Bicara tokoh (seseorang) harus dilihat dari dua sisi, ada sisi baik dan sisi buruk. Wayang adalah simbol gambaran hidup dengan segala permasalahannya sehingga berbicara tokoh harus ada keseimbangan antara kedua sisi tersebut.

Demikian juga dengan tokoh Rama-Shinta dalam pewayangan Ramayana sebagai simbol kesetiaan dan kesucian cinta menjadi panutan bagi orang Jawa bahkan di asal cerita itu dibuat, yaitu India. Gathotkaca tokoh yang berotot kawat dan berbalung (kerangka) besi , dan dapat terbang adalah simbol tokoh yang bertubuh kuat, pemberani dan siap bertempur di medan laga dalam pewayangan Mahabarata.

Tokoh Rama-Shinta, Gathotkaca dalam mertafora (8) mewakili tokoh zaman dulu dari budaya Timur, sedangkan zaman sekarang diwakili Si Madona penyanyi wanita seksi dan sensual, dan John Travolta lelaki seksi dari budaya Barat. Saat ini bukan lagi zaman dulu harus mengikuti perkembangan zaman, termasuk perilakunya, seperti metafora berikut ini:

(8) Pakle'...bu le' ...Rama-Shinta sekarang Madona 
Dulu Gathotkaca sekarang John Travolta (Jamrud: Priyayi).

Bidadari sebagai simbol wanita cantik dari kahyangan baik dari legenda di Cina maupun di Jawa. Satu dari tujuh bidadari, Nawangwulan, dalam folklor Jawa "Joko Tarub" adalah dewi yang cantik yang dapat dikawin oleh manusia. Cerita itu mengajarkan kecurangan akan selalu diketahui meskipun ditutup-tutupi secararapat. Bimbo dalam lagunya "Pesona di Bingkai Hati” memanfaatkan kecantikan bidadari dalam metaforanya.

(9) pesona di bingkai hatiku

terjerat tujuh bidadari

lembut mengagumkan

kerinduan

(Bimbo: Pesona di Bingkai Hati)

Demikian juga dengan nama Kartini atau SK Tri Murti adalah nama yang menjadi mitos semangat emansipasi bagi bangsa Indonesia, seperti metafora berikut ini:

(10) Jadilah Kartini atau SK Tri Murti perangi kebodohan

(Rita Ruby Harland: Dialog: Suami-Istri)

Kartini adalah wanita dari Jawa yang sangat terkenal pada zaman penjajahan Belanda dan punya sahabat dari Belanda. Keluhan dan perasaannya yang disampaikan pada sahabatnya itu kemudian dibukukan dengan judul "Habis Gelap Terbitlah Terang”. Melihat judul ini sudah bisa dimaknai adanya perubahan yang diinginkan wanita tidak sekedar konco wingking dan pasrah diatur keluarga dan ikut sesuai suami.

Demikian juga dengan nama SK Tri Murti wanita kelahiran Boyolali yang menjadi pejuang kemerdekaan setelah mendengar pidato Bung Karno pada saat pengibaran bendera merah putih yang pertama. Beliau juga seorang jurnalis wanita. Gambaran ini menunjukkan budaya berkembang sesuai keadaan dan situasinya; wanita yang biasanya tidak dipertimbangkan sebagai pekerjaan lelaki bisa dilakukan wanita. Dalam sejarah penjajahan di Indonesia muncul tokoh luar biasa jadi pemimpin dan maju di medan perang, yaitu Cut Nya Din, tokoh wanita dari Aceh.

\section{Metafora tentang Mode}

Penanda mode sebagai simbol dapat mengkongkeritkan pemaknaan. Mode dapat mewakili kurun waktu tertentu dengan perilaku manusianya. Busana sangat erat dengan 
perilaku manusia untuk menunjukkan eksistensinya dalam mengikuti perkembangan zaman, dan itu akan terus berlanjut. Misalnya:

(11) Malam Sabtu kujemput

Rok minimu menyambut (Jamrut: Telat Tiga Bulan)

Kata yang digunakan secara kode sastra ditunjukkan dengan rima akhir $u t$ dalam kata kujemput dan menyambut. Sedangkan kode budayanya terletak pada kata Malam Sabtu dan kata rok minimu. Malam sabtu (maksudnya malam minggu) adalah kebiasaan bagi remaja untuk apel yang sedang memadu cinta; Rok mini adalah mode dari barat yang masuk ke Indonesia yang sebenarnya sangat bertentangan dengan pribadi orang Indonesia yang berpakaian tertutup, seperti berkebaya, bersarung, berjilbab. Rok mini jelas jika dipakai menawarkan birahi bagi yang melihatnya karena hanya menutup di atas lutut, bahkan bergerak sedikit akan kelihatan celana dalamnya. Metafora (11) menggambarkan bahwa sang pacar sudah siap menyambut kedatangan pasangannya dengan birahinya. Risiko dari mode rok mini sudah jelas akan menimbulkan rangsangan ketika melihat lawan jenisnya menggunakan busana seperti itu.

Pacaran zaman dulu dengan sekarang jelas berbeda. Apel zman dahulu cukup bermain di rumah berbincang dengan keluarga jika bepergian atau menonton ada saudara, kakak, adik yang diajak sehingga tidak menimbulkan hal yang negatif. Berbeda dengan sekarang berpacaran artinya harus berduaan bahkan bisa melakukan yang dilarang, seperti pegang tangan, remas-remas tangan, pegang tubuh, berciuman bahkan bisa keblablasan.

\section{MetaforatentangMusik}

Musik tidak lepas dengan kehidupan manusia baik yang tradisional sampai yang modern. Musik dinikmati manusia sebagai sarana hiburan dan membawa suasana batin sesuai situasi maupun seleranya.

(12) ada nyanyian bambu-bambu seperti music simfoni Mengiringi anak-anak telanjang dan bermain berkejaran di pematang basah (Ebid G Ade: Jakarta I).

Musik simfoni adalah jenis musik modern yang dituli suntuk orkes lengkap, dimainkan orang banyak, dan berkesan klasik, seperti music karya Bethoven, Manthovani. Metafora 
dalam larik di atas menggambarkan suasana klasik di pedesaan dengan suara gesekan bambu-bambu yang terdengar seperti suara simfoni. Kebiasaan anak-anak di desa digambarkan juga dengan kebiasaan bermain tanpa memakai baju (bertenjang dada) di pematang sawah, kadang mereka terjebur di air sawah menjadi basah. Kata basah mengartikan juga kesegaran dan kebebasan bermain penuh riang. Bagi yang kelahirannya di desa suasana itu akan dialami. Perkembangan zaman hanya desa yang udik masih ada suasana tersebut. Sekarang desa sudah berubah, hutan bambu kecil dan lahan sawah menjadi rumah. Ruang bermain sudah sempit dan mengenal permainan ala kota bermain game dan ber-hp.

\section{MetaforatentangSenjata}

Senjata bagi manusia adalah alat untuk membela diri. Senjata itu bermacam-macam mulai dari yang tradisional sampai yang modern. Senjata dipakai sebagai alat beladiri.Senjata juga diyakini mempunyai tuah sehingga perlu diperlakukan khusus. Selain itu senjata juga dipakai sebagai kepentingan upacara ritual, dan pelengkap pakaian tradisional.

(13) Pak'e...bu'e... dulu nenteng keris sekarang nenteng compo

Dulu iseng nyirih sekarang main valas

(Jamrud: Ningrat).

Keris bagi orang Jawa adalah symbol kekuatan dan magis, seni yang antic dan unik (dibuat dengan berpuasa) lambang perjuangan dan kesengsaraan, dan juga kebanggaan yang harus dirawat dan dilestarikan. Dalam kegiatan ritual keris selalu dihadirkan, dan dipakai, misalnya acara pernikahan adatJawa, baik manten laki-laki, orang tua laki-laki penganten, sampai penerima tamu laki-laki; dalang ketika meruwat maupun memainkan wayang (ndalang). Sekarang benda itu tidak lagi sebagai barang yang diagung-agungkan sebagai klangenan yang dipamer-pamerkan, dan mewakili zaman dulu karena benda itu dikalahkan dengan teknologi, seperti compo (radio tape yang bisa untuk mendengarkan segala musik, dan berita) produk zaman sekarang. Simbol yang hendak dipaparkan dalam metafora (9) bahwa sekarang tidak lagi berharap pada produk tradisional, tetapi pada produk modern. Keris sekarang hanya dipakai sebagai pelengkap upacara saja tanpa ada magisnya meskipun ada sebagian yang masih memercayainya. Sebagian masih ada yang mengoleksi sebagai hiasan saja atau cindera mata pun ada yang masih percaya ada kekuatan magisnya 
dan merasa mempunyai kekuatan dan kebanggaan memiliki dan menyimpannya sebagai koleksi.

Keris kadang dipakai sebagai perlengkapan yang dimiliki dukun untuk menunjukkan benda itu mempunyai kekuatan gaib dan bertuah yang bisa mengobati penyakit nonmedis. Dalam perkembangan zaman kepercayaan ini sudah mulai luntur, artinya orang lebih percaya pada kemampuan medis untuk berobat.

Disebutkan kebiasaan zaman dulu orang sering nyirih makan daun sirih dicampur apudan buah kinang untuk memperkuat gigi, sekarang hal itu tidak dilakukan lagi lebih banyak memanfaatkan waktu dengan bermain valasjual beli uang asing. Ini menandakan adanya perubahan zaman ada perubahan perilaku.

\section{Metafora tentang Seni Pertunjukan}

Seni pertunjukkan dalam kehidupan manusia selain sebagai sarana hiburan juga sebagai sarana upacara ritual. Dalam perkembangannya seni pertunjukkan lebih banyak berperan sebagai sarana hiburan baik yang tradisional maupun yang modern. Lakon-lakon yang dipertunjukkan merupakan mimesis sehingga lakon-lakon itu merupakan gambaran kehidupan.

\section{(14) Macarin kamun ggak jauh beda dengan main ludruk}

Pake nanya silsilah, golongan darah, ningrat atau umum

(Jamrud: Ningrat).

Ludruk adalah seni pertunjukkan tradisional dari JawaTimur, ketoprak atau wayang orang kalau di Jawa Tengah, sebagai simbol tradisi lama karena di dalam permainannya dialognya/ceritanya cenderung menceritakan keningratan, missal cerita perjodohan pasti akan dibicarakan tentang, bibit, bobot, bebet sebagai silsilah keluarga yang harus diperhitungkan apakah dari golongan darah biru (bangsawan), priyayi, abangan dsb. Metafora dalam lirik (14) dengan symbol seni ludruk merupakan ungkapan perlawanan terhadap kaum ningrat. Dalam larik berikutnya memperkuat hal itu dikatakan oleh Jamrud bahwa sekarang bukan lagi zamannya. Sebenarnya tradisi menanyakan silsilah dalam perjodohan adalah hal yang baik. Perjodohan akan nyaman jika tidak ada isu negatif keluarganya karena kehati-hatian adalah hal yang harus dipikirkan. Zaman sekarang tidak 
lagi memerlukan semacam itu sebagai dasar perjodohan bahkan dengan nyinyir digambarkan oleh Jamrud sebagai berikut:

(15) Pak'e...bu'e... ini abad baru, bukan dunia wayang

Ngomong darah biru sekarang orang ketawa (Jamrud: Ningrat).

Kesenian tradisional seperti ludruk, wayang orang/ wayang kulit tidak lagi menjadi perhatian bahkansebagian besar generasi muda tidak mengenal kesenian tradisional tersaebut. Banyak tontonan kesenian tradisional dihidupkan tetap saja tidak banyak penontonnya. Generasi muda pun sedikit sekali yang mau melestarikan terlibat berkesenian tradisional. Hal ini wajar, perkembangan zaman ada kesenian modern bahkan kontemporer mematikan kesenian tradisional. Kesenian tradisional monoton dan minim inovasi. Sementara kesenian modern selalu berinovasi juga medianya mengikuti perkembangan teknologi baik tatalampu, musik, tatapanggung, tatarias dan medianya dalam bentuk film maupun sinetron. Kesenian modern sifatnya sekali tonton, selesai sedangkan kesenian tradisional monoton dan harus dinikmati berulang-ulang. Jelas membosankan dan sudah tahu alur cerita dan pertunjukkannya.

\section{Simpulan}

Memahami lirik lagu tidak hanya memahami kode bahasanya saja, tetapi memerlukan kode sastra dan kode budayanya. Kode bahasa dalam lirik terlihat dalam wujud dasarnya adalah rangkaian kata yang bermakna. Kata-kata tersebut dipakai dalam menunjukkan keindahannya diwujudkan sebagai puisi atau lirik yang makna katanya figuratif. Katakata figuratif itu terlihat dalam unsur intrinsik karya sastra berdiksi majas dst. Kata-kata tersebut dipakai pengarang sebagai sarana kreativitas melalui realita yang ada berupa kode budaya. Budaya yang hidup dimasyarakat dipakai sebagi simbol metaforis yang mencereminkan pengalaman dan pengetahuannya. Bagi penikmat, karya itu dapat diterima jika ada pengetahuan yang sama tentang kode budaya tersebut.

\section{Daftar Pustaka}

Aminuddin. 2000. Pengantar Apresiasi Karya Sastra. Bandung: Sinar Baru.

Hermintoyo, M. 2017. Kode Bahasa dan Sastra. Semarang: Gigih Pustaka Mandiri.

Luxemburg, Jan Van; Mieke Bal; Willem G. Weststeijn. 1984. Pengantar Ilmu Sastra. Terjemahan Dick Hartoko. Jakarta: Gramedia 
Pradopo, Rahmat Djoko. 1987. Pengkajian Puisi. Yogya: Gajah Mada University Press.

Preminger, Alex.2001. "Semiotik (Semiologi)". Terjemahan Rahmat Djoko Pradopo dalam Metodologi Penelitian Sastra. (Ed.) Jabrohim. Yogyakarta: Hanindita.

Sudaryono.2000. "Ketaksaan dalam Komunikasi Verbal," dalam Kajian Sastra. Nomor 1, Tahun XXIV. Semarang: Fakultas Sastra Undip.

Suyono.1990. Pragmatik Dasar-dasar dan Pengajarannya. Malang: IKIP Malang.

Teeuw, A. 1983. Membaca dan Menilai Sastra. Jakarta: Gramedia.

Waluyo, Herman J. 1987.Teori dan Apresiasi Puisi.Jakarta: Erlangga.

Wedhawati.1993. "Trier dan Teori Medan Kata," dalam WidyaparwaNo.14.Oktober. Yogyakarta: Balai Penelitian Bahasa. 